\title{
UJI AKTIVITAS ANTIOKSIDAN EKSTRAK BUAH SEMANGKA (Citrullus lanatus)
}

\author{
Antioxidant Activity Test of Watermelon (Citrullus ianatus) Fruit Extracts
}

\section{*Sri Mariani, Nurdin Rahman dan Supriadi}

Pendidikan Kimia/FKIP - Universitas Tadulako, Palu - Indonesia 94118

Received 21 March 2018, Revised 23 April 2018, Accepted 21 May 2018

\begin{abstract}
The aim of this study is determine the $I C_{50}$ extracts values of white peel and flesh of red watermelon, white peel and flesh of yellow watermelon as antioxidants. To determine antioxidant activities DPPH reagent was used as well as UV-Vis Spectrophotometry was used to measure vitamin $C$ as a positive control measurement. The samples mixed with ethanol in various concentration of 5, 15, 25 and $35 \mathrm{mg} / \mathrm{L}$. The results showed that the $I C_{50}$ values for each extract of red watermelon flesh, yellow watermelon flesh, white peel of red watermelon, and white peel of yellow watermelon were $16.619 \mathrm{mg} / \mathrm{L}, 16.575 \mathrm{mg} / \mathrm{L}, 14.729 \mathrm{mg} / \mathrm{L}$, and $16.782 \mathrm{mg} / \mathrm{L}$, respectively. Vitamin $C$ as the positive control has $I C_{50}$ value of $9.526 \mathrm{mg} / \mathrm{L}$. These $I C_{50}$ values showed that vitamin $C$ had higher antioxidant activity than watermelon extracts, but the extracts of watermelon still categorized in strong natural antioxidants. This study concluded that watermelon is good to be consumed because it is a very strong antioxidant.
\end{abstract}

Keywords: Antioxidant, watermelon, DPPH, vitamin C, IC $_{50}$, Vitamin C, Spectrophotometry

\section{Pendahuluan}

Buah semangka (citrullus lanatus) termasuk dalam golongan labu-labuan dan melon. Buah semangka merupakan buah yang banyak digemari oleh masyarakat karena rasanya yang manis dan baik bagi kesehatan. Buah semangka banyak terdapat kandungan zat-zat yang sangat berguna bagi kesehatan tubuh manusia. Kandungan dari zat-zat tersebut dapat bermanfaat untuk melindungi jantung, memperlancar pengeluaran urine, dan menjaga kesehatan kulit. Fungsi buah semangka tidak hanya dapat menghilangkan dahaga tetapi juga sebagai antioksidan yang baik. Buah semangka dapat diandalkan sebagai penetral radikal bebas dan mengurangi kerusakan sel dalam tubuh karena memiliki kadar antioksidan yang tinggi (Rochmatika, dkk., 2012).

Buah semangka mengandung banyak air (sekitar $92 \%$ ) dan mengandung likopen sebesar 48,8 \% (Tadmor, dkk., 2005). Pada lapisan putih buah semangka yang kurang dimanfaatkan memiliki kandungan zat-zat yang penting bagi kesehatan dan diperlukan oleh tubuh, Salah satunya adalah sitrulin. Sitrulin merupakan salah satu zat antioksidan yang bermanfaat bagi kesehatan kulit (Rochmatika, dkk., 2012)

Antioksidan merupakan senyawa yang dapat menghambat reaksi oksidasi, dengan mengikat radikal bebas dan molekul yang sangat reaktif (Winarsi, 2007). Senyawa antioksidan akan menyerahkan satu atau lebih elektron kepada senyawa radikal bebas sehingga menjadi bentuk

*Correspondence

Sri Mariani

Program Studi Pendidikan Kimia, Fakultas Keguruan dan Ilmu Pendidikan, Universitas Tadulako

e-mail: srimariani82@gmail.com

Published by Universitas Tadulako 2018 molekul yang normal kembali dan menghentikan berbagai kerusakan yang akan ditimbulkan (Sasikumar, dkk., 2009).

Fungsi utama antioksidan digunakan sebagai upaya memperkecil terjadinya proses oksidasi dari lemak dan minyak, memperkecil proses kerusakan dalam makanan. Adanya kekhawatiran akan kemungkinan efek samping yang belum diketahui dari antioksidan sintetik menyebabkan antioksidan alami menjadi alternatif yang sangat dibutuhkan (Sartika, 2012). Serta antioksidan dapat berfungsi sebagai penangkap radikal bebas, pembentuk kompleks dengan logam-logam pro oksidan dan berfungsi sebagai senyawa pereduksi (Yulia, 2007).

Senyawa antioksidan alami akhir-akhir ini banyak dikaji oleh berbagai peneliti sebagai komponen pangan fungsional dan suplemen makanan. Hal tersebut disebabkan fungsi antioksidan dalam tubuh yang dapat mencegah berbagai jenis penyakit yang disebabkan oleh radikal bebas seperti kanker dan jantung koroner, sehingga membuat banyak peneliti yang ingin menguji beberapa tumbuhan yang dapat dikonsumsi (Andayani, dkk., 2008), karena radikal bebas sangat berbahaya bagi makhluk hidup karena apabila reaksi ini terjadi di dalam tubuh, maka akan menimbulkan berbagai kerusakan yang menjadi penyebab berbagai penyakit (Simajuntak, dkk., 2004). Senyawa radikal juga menyebabkan terjadinya proses penuaan akibat rusaknya sel-sel jaringan tubuh serta dapat menimbulkan penyakit autoimun (Muchtadi, 2000).

Pengujian antioksidan biasanya menggunakan metode DPPH (2,2-difenil-1-pikrilhidrazil). DPPH merupakan radikal yang stabil yang banyak digunakan untuk mengetahui aktivitas antioksidan ekstrak tumbuhan. Metode DPPH ini dapat digunakan pada sampel padatan maupun dalam bentuk larutan dan tidak spesifik untuk komponen antioksidan tertentu. Metode ini digunakan karena 
menurut Rosyana (2012) penggunaanya sederhana, akurat, cepat, dan murah untuk percobaan kemampuan komponen dalam menangkap senyawa radikal bebas. Pada metode pengujian ini, DPPH berperan sebagai radikal bebas yang direndam oleh antioksidan dari bahan uji, dimana DPPH berperan sebagai akan bereaksi dengan antioksidan tersebut membentuk 2,2-difenil-1pikrilhidrazin (Juniarti \& Yuhernita, 2009).

Untuk menginterpretasikan hasil pengujian dengan metode $\mathrm{DPPH}$ adalah $\mathrm{IC}_{50}$ (inhibition concentration), dimana $\mathrm{IC}_{50}$ merupakan konsentrasi larutan sampel yang akan menyebabkan reduksi terhadap aktivitas DPPH sebesar 50\% (Molyneux, 2004).

Tulisan ini dimaksudkan untuk mendeskripsikan hasil uji aktivitas antioksidan ekstrak buah semangka dengan cara menentukan nilai $\mathrm{IC}_{50}$ ekstrak kulit putih dari semangka merah dan kuning dan daging buah semangka merah dan kuning.

\section{Metode}

Alat yang digunakan dalam penelitian ini adalah Pisau, oven, corong, neraca digital, blender, spektrofotometer UV-Vis (T80 ${ }^{+}$PG Intruments ltd), gelas ukur, gelas kimia, batang pengaduk, ayakan 10 mesh, labu ukur, rotary evaporator (EYELA SB-1100), spatula, erlenmeyer, pipet ukur, pipet tetes, kertas saring dan aluminium foil.

Bahan yang digunakan ekstrak daging merah, kulit putih dan daging kuning buah semangka, etanol p.a. (J.T. BAKER), vitamin C (Merck) dan padatan DPPH (2,2-difenil-2-pikrilhidrazil) (Aldrich).

\section{Perlakuan preparasi sampel}

Buah semangka merah dibelah, lalu dipisahkan antara daging merah, daging putih dan kulitnya. Daging merah dan putih diiris kecil-kecil sedangkan kulitnya dibuang. Daging buah semangka diperas untuk menghilangkan sedikit kandungan airnya. Setelah itu daging merah dan putih semangka dikeringkan dengan dioven selama $2 \times 24$ jam pada suhu $48{ }^{\circ} \mathrm{C}$, lalu dihancurkan menggunakan blender, kemudian sampel yang telah halus siap untuk diekstraksi. Perlakuan yang sama untuk sampel buah semangka kuning.

\section{Ekstraksi sampel}

10 gram daging merah buah semangka yang telah halus dimaserasi dengan $100 \mathrm{~mL}$ etanol. Dalam Erlenmeyer dan didiamkan selama $2 \times 24$ jam. Setelah itu disaring menggunakan kertas saring untuk memisahkan residu dan filtratnya. Kemudian residunya dimaserasi kembali dengan pelarut etanol, kemudian filtrate hasil maserasi pertama ditambahkan dengan filtrat hasil maserasi kedua diuapkan pelarutnya menggunakan rotary evaporator, sehingga diperoleh ekstrak pekat pada daging merah buah semangka. Perlakuan yang sama dilakukan untuk daging putih dan daging kuning buah semangka.

\section{Pembuatan larutan dan pengukuran}

$1,25 \mathrm{mg}$ DPPH dilarutkan dengan etanol absolute ke dalam labu ukur $25 \mathrm{~mL}$, kemudian dicukupkan volumenya dengan etanol absolute sampai garis tanda batas.

Masing-masing 2,5 mg ekstrak daging merah dan daging putih (semangka merah), serta daging kuning dan daging putih (semangka kuning), dilarutkan ke dalam labu ukur $25 \mathrm{ml}$ kemudian dicukupkan dengan etanol sampai tanda batas.

2,5 mg vitamin C dimasukkan ke dalam labu ukur $25 \mathrm{~mL}$ ditambahkan aquades secukupnya dan dicukupkan dengan etanol sampai tanda batas.

Sebanyak $1,25,3,75,6,25$ dan $8,75 \mathrm{~mL}$ larutan induk dimasukkan ke dalam labu ukur $25 \mathrm{~mL}$. Masing-masing larutan ditambahkan $1 \mathrm{~mL}$ larutan DPPH, kemudian ditambahkan etanol sampai tanda batas, kemudian masing-masing larutan diukur menggunakan spektrofotometer UV-Vis pada panjang gelombang $517 \mathrm{~nm}$.

$1,25,3,75,6,25$ dan $8,75 \mathrm{~mL}$ larutan vitamin C pembanding dimasukkan ke dalam labu ukur 25 mL. Larutan masing-masing ditambahkan $1 \mathrm{~mL}$ larutan DPPH Kemudian ditambahkan etanol sampai tanda batas, kemudian larutan masingmasing diukur dengan menggunakan spektrofotometer UV-Vis pada panjang gelombang $517 \mathrm{~nm}$.

Larutan DPPH sebagai blanko diambil sebanyak $1 \mathrm{~mL}$, kemudian dimasukkan ke dalam labu ukur $25 \mathrm{~mL}$ dan dicukupkan volumenya dengan etanol sampai tanda batas, setelah itu larutan didiamkan selama 30 menit. Larutan diukur dengan menggunakan spektrofotometri UV-Vis pada panjang gelombang $517 \mathrm{~nm}$.

\section{Hasil dan Pembahasan}

\section{Aktivitas antioksidan ekstrak buah semangaka}

Pelaksanaan uji aktivitas antioksidan ekstrak buah semangka dilakukan dengan menggunakan metode DPPH. Metode ini digunakan karena sangat sederhana untuk mengukur kemampuan antioksidan dalam menangkap radikal bebas serta ujinya sederhana dan cepat. Serta hanya memerlukan sedikit bahan yang digunakan (Hanani, dkk., 2005).

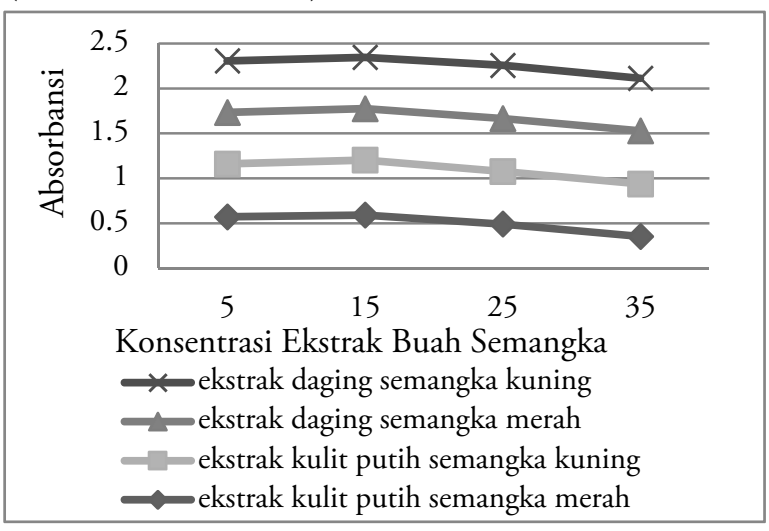

Gambar 1. Nilai absorbansi DPPH ekstrak buah semangka 
Menurut Utomo (2008) metode pengujian menggunakan DPPH merupakan metode yang konvensional dan telah lama digunakan untuk penetapan aktivitas senyawa antioksidan. Pengukuran aktivitas antioksidan pada sampel dilakukan menggunakan spektrofotometri UV-Vis pada panjang gelombang $517 \mathrm{~nm}$ yang merupakan panjang gelombang maksimum DPPH.

Hasil penelitian untuk nilai absorbansi ekstrak buah semangka (kulit putih semangka merah, kulit putih semangka kuning, aging semangka merah dan daging semangka kuning) setelah diukur serapan absorbansinya dapat dilihat pada Gambar 1.

Berdasarkan Gambar 1, dapat dilihat bahwa perbedaan nilai absorbansi yang diperoleh dari keempat sampel tidak terlalu memiliki perbedaan. Nilai absorbansi ekstrak buah semangka (kulit putih semangka merah, kulit putih semangka kuning, daging semangka merah dan daging semangka kuning) terlihat tidak linear seiring dengan meningkatnya konsentrasi. Hal ini tidak sesuai dengan hukum Lambert-Beer, yang menyatakan bahwa konsentrasi suatu sampel berbanding lurus dengan absorbansi, atau semakin tinggi konsentrasi maka semakin tinggi pula nilai absorbansi suatu sampel, dimana untuk sampel ekstrak kulit putih semangka merah dan ekstrak kulit putih semangka kuning pada konsentrasi 5 $\mathrm{mg} / \mathrm{L}$ ke konsentrasi $15 \mathrm{mg} / \mathrm{L}$ mengalami kenaikan nilai absorbansi, sedangkan pada konsentrasi 15 sampai $35 \mathrm{mg} / \mathrm{L}$ nilai absorbansinya menurun. Hal ini dapat dijelaskan bahwa adanya aktivitas antioksidan pada sampel di tandai dengan perubahan warna DPPH dari ungu gelap menjadi ungu terang pada konsentrasi $35 \mathrm{mg} / \mathrm{L}$ untuk sampel ekstrak kulit putih semangka merah dan ekstrak kulit putih semangka kuning warna DPPH berkurang. Hal ini dikarenakan semakin tinggi konsentrasi ekstrak kulit putih semangka merah dan ekstrak kulit putih semangka kuning maka partikel-partikel senyawa antioksidan yang terkandung akan semakin banyak sehingga semakin besar aktivitas antioksidannya dan menyebabkan absorbansi pada kosentrasi $15 \mathrm{mg} / \mathrm{L}$ sampai $35 \mathrm{mg} / \mathrm{L}$ menurun. Sedangkan untuk sampel ekstrak daging semangka merah pada konsentrasi $5 \mathrm{mg} / \mathrm{L}$ ke konsentrasi $15 \mathrm{mg} / \mathrm{L}$ mengalami penurunan nilai absorbansi. Hal ini dikarenakan semakin tinggi konsentrasi ekstrak daging semangka merah maka partikel-partikel senyawa antioksidan yang terkandung akan semakin banyak sehingga semakin besar pula aktivitas antioksidannya dan menyebabkan absorbansinya semakin berkurang (Talapessy, dkk., 2013).

Sedangkan pada konsentrasi 15 sampai 35 $\mathrm{mg} / \mathrm{L}$ mengalami kenaikan nilai absorbansi dengan meningkatnya konsnetrasi. Hal ini dikarenakan pada konsentrasi larutan sampel tersebut kurang baik aktivitas antioksidannya sehingga absorbansinya meningkat dan untuk ekstrak daging semangka kuning, pada konsentrasi $5 \mathrm{mg} / \mathrm{L}$ ke konsentrasi $15 \mathrm{mg} / \mathrm{L}$ mengalami penurunan nilai absorbansi sedangkan pada konsentrasi 15 ke $25 \mathrm{mg} / \mathrm{L}$ nilai absorbansinya meningkat dan mengalami penurunan kembali pada konsentrasi $35 \mathrm{mg} / \mathrm{L}$. Hal ini dapat dijelaskan bahwa adanya aktivitas antioksidan pada sampel ditandai dengan perubahan warna DPPH dari ungu gelap menjadi ungu terang. Pada konsentrasi $35 \mathrm{mg} / \mathrm{L}$ warna DPPH berkurang. Hal ini dikarenakan semakin tinggi konsentrasi ekstrak daging semangka kuning maka partikel-partikel senyawa antioksidan yang terkandung akan semakin banyak sehingga semakin besar aktivitas antioksidannya dan menyebabkan absorbansinya menurun. Dari nilai absorbansi sampel yang diperoleh maka diperoleh pula persentase penghambat aktivitas antioksidan pada Gambar 2.

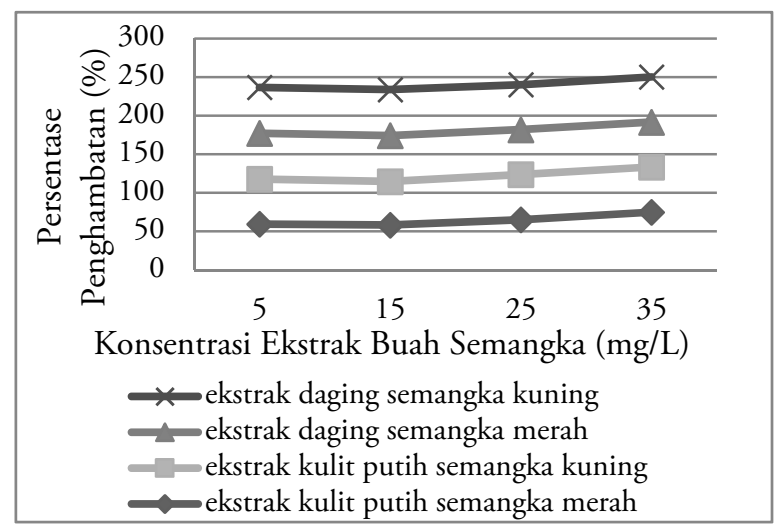

Gambar 2. Aktivitas antioksidan ekstrak buah semangka

Berdasarkan Gambar 2 dapat diketahui bahwa konsentrasi DPPH juga menunjukkan bahwa semakin besar konsentrasi ekstrak buah semangka, semakin besar pula persentasi penghambat radikal bebas DPPH. Pada sampel kulit putih semangka merah konsentrasi tertinggi dari variasi konsentrasi yang diujikan yakni $35 \mathrm{mg} / \mathrm{L}$ memiliki persentase penghambatan radikal bebas sebesar 74,9\%. Hasil persentase penghambatan radikal bebas mendukung hasil pengamatan warna larutan DPPH setelah ditambahkan ekstrak kulit putih semangka merah. Warna DPPH yang berkurang lebih banyak memiliki persentase penangkapan radikal bebas, yang berarti bahwa cahaya lebih banyak diteruskan dan cahaya yang diserap lebih sedikit, untuk sampel ekstrak kulit putih semangka kuning konsentrasi tertinggi dari variasi konsentrasi yang diujikan yakni $35 \mathrm{mg} / \mathrm{L}$ memiliki persentase penghambatan radikal bebas sebesar $58,65 \%$ dan konsentrasi $15 \mathrm{mg} / \mathrm{L}$ memiliki persentase penghambatan radikal bebas sebesar $56,59 \%$. Pada ekstrak daging semangka merah, persentase penghambatan pada konsentrasi $5 \mathrm{mg} / \mathrm{L}$ ke $15 \mathrm{mg} / \mathrm{L}$ semakin besar sedangkan pada konsentrasi $15 \mathrm{mg} / \mathrm{L}$ sampai $35 \mathrm{mg} / \mathrm{L}$ persentase penghambatan semakin kecil. Hal ini dapat dilihat pada gambar diatas. Konsentrasi tertinggi dari variasi konsentrasi yang diujikan yakni $15 \mathrm{mg} / \mathrm{L}$ memiliki persentase penghambatan radikal bebas sebesar 59,51\% dan konsentrasi yang terkecil yaitu 
pada $35 \mathrm{mg} / \mathrm{L}$ memiliki persentase penghambatan radikal bebas sebesar 58,09 \%. Sedangkan untuk sampel ekstrak daging semangka kuning persentase penghambatan pada konsentrasi $5 \mathrm{mg} / \mathrm{L}$ ke 15 $\mathrm{mg} / \mathrm{L}$ mengalami kenaikan sedangkan pada konsentrasi 15 ke $25 \mathrm{mg} / \mathrm{L}$ persentase penghambatan mengalami penurunan, dan persentase penghambatan dari $25 \mathrm{ke} 35 \mathrm{mg} / \mathrm{L}$ mengalami kenaikan kembali. Hal ini dapat dilihat dari Gambar 2. Konsentrasi tertinggi dari variasi konsentrasi yang diujikan yakni $15 \mathrm{mg} / \mathrm{L}$ memiliki persentase penghambatan radikal bebas sebesar $59,51 \%$ dan konsentrasi yang terkecil yaitu pada $25 \mathrm{mg} / \mathrm{L}$ memiliki persentase penghambatan radikal bebas sebesar 58,15\%. Hasil persentase penghambatan radikal bebas mendukung hasil pengamatan warna larutan DPPH setelah ditambahkan ekstrak buah semangka (kulit putih semangka merah, kulit putih semangka kuning, daging semangka merah dan daging semangka kuning). Warna DPPH yang berkurang lebih banyak memiliki persentase penangkapan radikal bebas, yang berarti bahwa cahaya lebih banyak diteruskan dan cahaya yang diserap lebih sedikit.

\section{Uji aktivitas antioksidan vitamin $C$}

Pada perlakuan uji aktivitas antioksidan vitamin C digunakan variasi konsentrasi yang sama dengan ekstrak buah semangka yaitu 5, 15, 25 dan 35 $\mathrm{mg} / \mathrm{L}$. Tujuan penggunaan konsentrasi yang sama dengan ekstrak buah semangka yaitu agar peneliti bisa membandingkan aktivitas antioksidan antara ekstrak buah semangka dengan vitamin C. Dari hasil penelitian yang dilakukan diperoleh nilai absorbansi DPPH dapat dilihat pada Gambar 3.

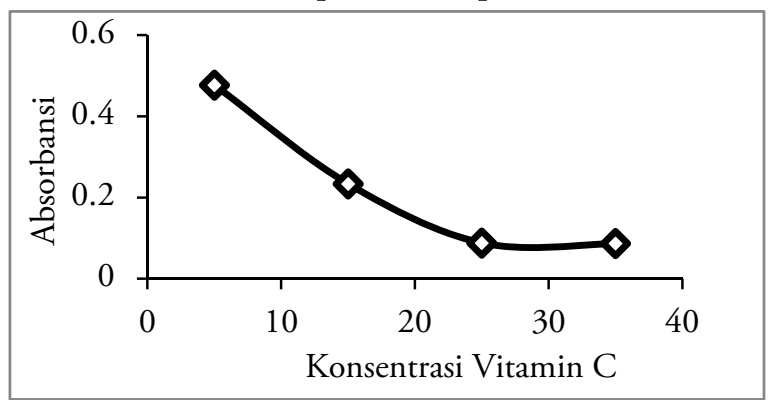

Gambar 3. Absorbansi DPPH

Pada Gambar 3. Diperoleh bahwa peningkatan konsentrasi vitamin $C$ dari $5 \mathrm{mg} / \mathrm{L}$ sampai 35 $\mathrm{mg} / \mathrm{L}$ mempengaruhi tingkat kemampuan vitamin $\mathrm{C}$ untuk meredam radikal bebas DPPH sehingga nilai absorbansinya menurun. Sehingga semakin tinggi konsentrasi vitamin $\mathrm{C}$ maka semakin kuat vitamin $\mathrm{C}$ dalam menangkap radikal bebas $\mathrm{DPPH}$.

Berdasarkan absorbansi yang diperoleh dari hasil penelitian maka diperoleh juga hasil perentase penghambatan aktivitas antioksidan dari vitamin $\mathrm{C}$ yang disajikan pada Gambar 4

Pada Gambar 4 menunjukkan bahwa peningkatan konsentrasi vitamin $\mathrm{C}$ dari $5 \mathrm{mg} / \mathrm{L}$ sampai $35 \mathrm{mg} / \mathrm{L}$ mengalami peningkatan. Hal tersebut menunjukkan bahwa semakin besar konsentrasi vitamin $\mathrm{C}$ maka semakin besar pula persentase penghambatan radikal bebas DPPH yang terjadi. Hal ini disebabkan karena semakin besar konsentrasi vitamin $\mathrm{C}$, maka semakin banyak partikel-partikel yang dapat mengoksidasi partikelpartikel dari radikal bebas DPPH yang ada.



Gambar 4. Aktivitas antioksidan vitamin C

\section{Perbandingan aktivitas penangkap radikal bebas ekstrak buah semangka dengan kontrol vitamin $C$ \\ Hasil penelitian yang dilakukan ini} membandingkan aktivitas antioksidan ekstrak buah semangka (kulit putih semangka merah, kulit putih semangka kuning, daging semangka merah dan daging semangka kuning) dengan vitamin C sebagai kontrol positifnya memiliki perbedaan yang tidak terlalu jauh. Hal ini dapat ditinjau dari persentase penangkapan radikal bebas dari sampel ekstrak semangka (kulit putih semangka merah, kulit putih semangka kuning, daging semangka merah dan daging semangka kuning) yang digunakan sebagai tinjauan utama dalam penelitian ini tidak terlalu jauh dengan persentase penangkapan radikal bebas dari vitamin $\mathrm{C}$ yang merupakan kontrol positif dari penelitian ini. Perbandingan persentase penangkapan radikal bebas dari ekstrak semangka (kulit putih semangka merah, kulit putih semangka kuning, daging semangka merah dan daging semangka kuning) dan vitamin C dapat dilihat pada Gambar 5

Gambar 5. Perbandingan persentase hambatan ekstrak buah semangka dan vitamin C

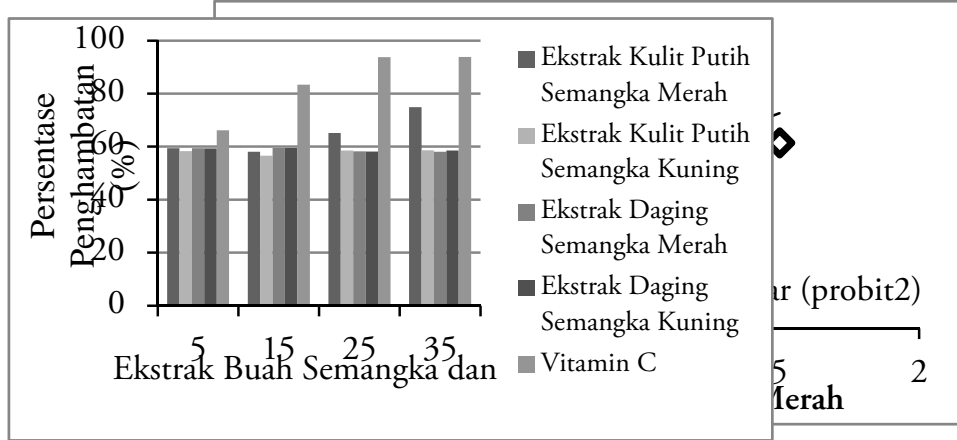

Berdasarkan Gambar 5 terlihat bahwa perbedaan persentase penghambatan antara ekstrak buah semangka (kulit putih semangka merah, kulit putih semangka kuning, daging semangka merah, dan daging semangka kuning) dengan vitamin $\mathrm{C}$ tidak terlalu memiliki perbedaan. Hal ini membuktikan bahwa ekstrak buah semangka memiliki kemampuan sebagai antioksidan yang hampir sama dengan vitamin C. Persentase penghambatan ekstrak buah semangka dikatakan sangat baik walaupun konsentrasinya lebih kecil 
dibandingkan dengan konsentrasi vitamin $\mathrm{C}$ sebagai kontrol positif. Oleh karena itu, ekstrak buah semangka sangat baik dimanfaatkan sebagai bahan antioksidan alami.

\section{Pengukuran $I C_{50}$ ekstrak kulit putih semangka merah}

Nilai $I C_{50}$ diperoleh dari beberapa tahapan yaitu menghitung nilai log konsentrasi dan nilai probit untuk masing-masing persentase aktivitas penghambat radikal bebas DPPH. Selanjutnya menghubungkan kedua data dari perhitungan yang diperoleh dalam 1 grafik utuh, dengan persamaan regresi linier sederhana yaitu, $y=a x+b$, dimana nilai log konsentrasi dijadikan sebagai sumbu $\mathrm{x}$ dan nilai probit digunakan sebagai sumbu y. sehingga dapat dilihat pada Gambar 6-10.

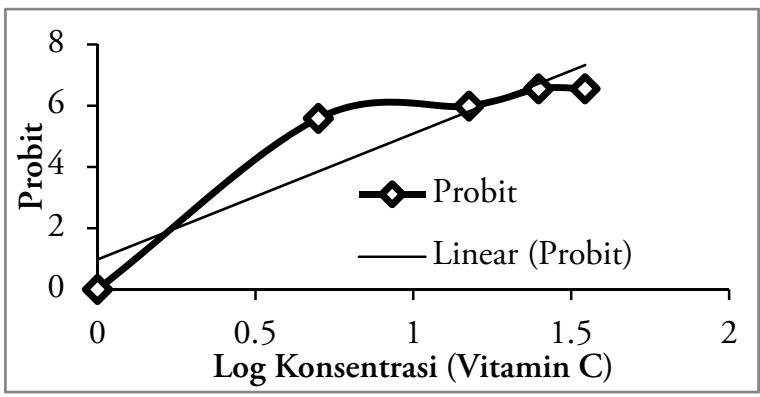

Gambar 6. Hubungan log konsentrasi dan probit vitamin $\mathrm{C}$

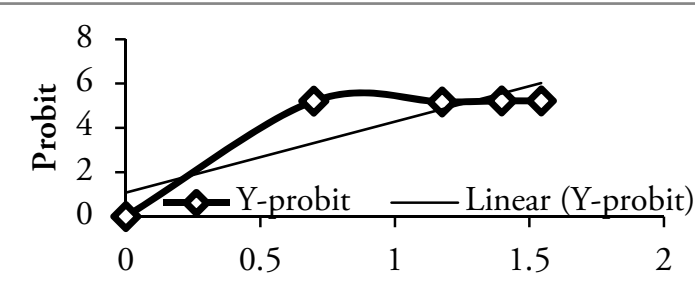

Log Konsentrasi (Ekstrak Kulit Putih...

Gambar 7. Hubungan log konsentrasi dan probit ekstrak kulit putih semangka merah



Gambar 8. Hubungan log konsentrasi dan probit ekstrak kulit putih semangka kuning

Gambar 9. Hubungan log konsentrasi dan probit ekstrak daging semangka merah

Gambar 10. Hubungan log konsentrasi dan probit ekstrak daging semangka kuning

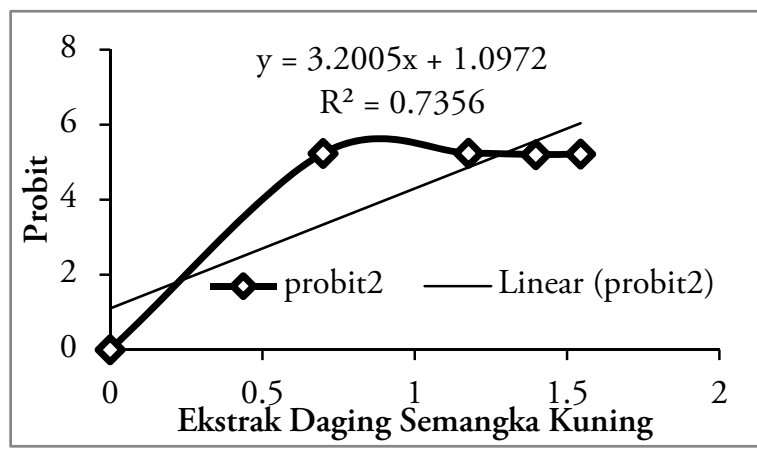

Berdasarkan Gambar 6-10 diperoleh nilai untuk regresi linier $y=4,109 x+0,975$ untuk vitamin $\mathrm{C}$ sebagai kontrol positif dan untuk buah semangka (kulit putih semangka merah, kulit putih semangka kuning, daging semangka merah dan daging kuning semangka kuning) sebagai sampel diperoleh nilai untuk regresi linier secara berturut turut yaitu $\mathrm{y}=3,4135 \mathrm{x}+1,0122$ untuk ekstrak kulit putih semangka merah, $y=3,1997 x+1,0808$ untuk kulit putih semangka kuning, $y=3,954 \mathrm{x}+$ 1,0998 untuk daging semangka merah dan $\mathrm{y}=$ $3,2005 x+1,0972$ untuk ekstrak daging semangka kuning sebagai sampel. Pada Gambar 6 sampai Gambar 10. Diperoleh juga nilai $r$ dari ekstrak buah semangka (kulit putih semangka merah, kulit putih semangka kuning, daging semangka merah dan daging semangka kuning) secara berturut-turut adalah 0,$7861 ; 0,7412 ; 0,734 ; 0,7356$ dan vitamin C sebagai kontrol positif adalah 0,8512. Dari data nilai $r$ yang diperoleh maka data probit dari vitamin $\mathrm{C}$ lebih baik dibandingkan dengan sampel ekstrak buah semangka (kulit putih semangka merah, kulit putih semangka kuning, daging semangka merah dan daging semangka kuning). Sehingga dari hasil penelitian yang dilakukan maka dapat dikatakan nilai $r$ untuk vitamin $C$ dan ekstrak kulit putih semangka merah yang diperoleh cukup baik.

\section{Kesimpulan}

Nilai $\mathrm{IC}_{50}$ yang diperoleh dari sampel ekstrak buah semangka (kulit putih semangka merah, kulit putih semangka kuning, daging semangka merah dan daging semangka kuning) yang diperoleh dari grafik secara berturut-turut yaitu 14,729, 16,782, 16,619 dan $16,575 \mathrm{mg} / \mathrm{L}$, dan keempat sampel ini tergolong sebagai antioksidan alami yang sangat kuat.

\section{Ucapan Terima Kasih}

Penulis mengucapkan terima kasih kepada kepala sekolah SMA Negeri 6 Palu, guru kimia di SMA Negeri 6 Palu, siswa-siswa kelas XI IPA SMA Negeri 6 Palu serta semua pihak yang telah membantu penulis dalam penyelesaian penelitian ini.

\section{Referensi}

Andayani, R., Maimunah \& Lisawati, Y. (2008). Penentuan aktivitas antioksidan, kadar fenolat total dan likopen pada buah tomat (slanum lycopersicium 1). Jurnal Sains dan Teknologi Farmasi, 13(1), 31-37.

Hanani, E., Mun'im, A. \& Sekarini, R. (2005). Identifikasi senyawa antioksidan dalam spons callyspongia sp dari kepulauan seribu. Majalah Ilmu Kefarmasian, 2(3), 127-133.

Juniarti, O. D. \& Yuhernita. (2009). Kandungan senyawa kimia, uji toksitas (BSLT) dan antioksidan (1,1-diphenyl-2-pikrilhidrazyl) dari ekstrak daun saga. Makara Sains, 13(1), 50-54. 
Molyneux, P. (2004). The use of the stable 6 . free radical diphenylpicryl-hydrazyl (DPPH) for estimating antioxidant activity. Songklanakarin Journal of Science Technology, 26(2), 211-219.

Muchtadi, D. (2000). Sayur-sayuran sumber serat dan antioksidan: mencegah penyakit degenerati. Bogor: Institut Pertanian Bogor.

Rochmatika, L. D., Kusumastuti, H., Setyaningrum, G. D. \& Muslihah, N. I. (2012). Analisis kadar antioksidan pada masker wajah berbahan dasar lapisan putih kulit semangka (citrullus vulgaris schrad). Seminar Nasional Penelitian, Pendidikan dan Penerapan MIPA.

Rosyana, A. (2012). Aktivitas antioksidan dan penghambat -glikosidase ekstrak dan nanopartikel ekstrak kulit kayu mahoni (switenia macrophylla king). Bogor: IPB.

Sartika. (2012). Kajian aktivitas antioksidan ekstrak etanol kulit ari biji kakao (theobroma cacao l). Universitas Tadulako, Palu.

Sasikumar, J. M., Mahesu, V. \& Jayadev, R. (2009). In vitro antioxidant activity og methanolic extracts of berbens tinctoria lesch root and root bark. Journal of Herbal Medicine and Toxycologi, 3(2), 53-58.
Simajuntak, P., Parwati, T., L. E Lenny, Tamat, S. R. \& Murwani, R. (2004). Isolasi dan identifikasi antioksidan dari ekstrak benalu teh (scurrulaoortiana (korth) danser). Jurnal Ilmu Kefarmasian Indonesia, 5(1), 19-24.

Tadmor, Y., King, S., Levi, A., Davis, A. \& Hirschberg, J. (2005). Comparative fruit colouration in watermelon and tomato. Food Research International, 38, 837-841.

Talapessy, S., Suryanto, E. \& Yudistira, A. (2013). Uji aktivitas antioksidan dari ampas hasil pengolahan sagu (metroxylon sagu rottb). Jurnal Ilmiah Farmasi-UNSRAT, 2(3), 40-44.

Winarsi, H. (2007). Antioksidan alami dan radikal bebas. Yogyakarta: Kanisius.

Yulia, O. (2007). Pengujian kapasitas antioksidan ekstrak, polar, non polar, fraksi protein dan nonprotein kacang komak (lablab purpureus (l) sweet. Bogor: Institut Pertanian Bogor.

Zuhra, C. F., Taringan, J. B. \& Sitohang, H. (2008). Aktivitas antioksidan senyawa flavonoid dari daun katuk (sauropus androgunus (1) merr). Jurnal Biologi Sumatera, 3(1), 7-10. 